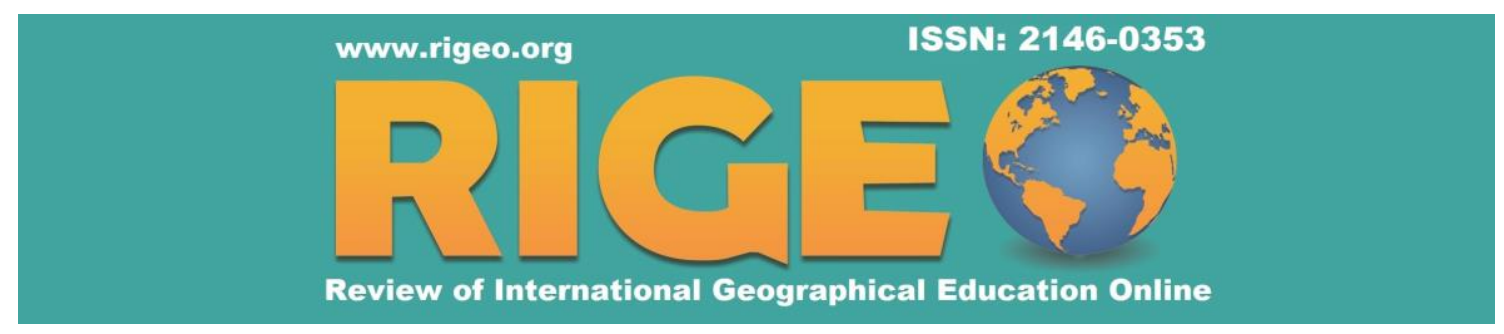

Review of International Geographical Education Online

(C) RIGEO Volume 9, Number 2, Summer 2019

Research Article

Copyright @ RIGEO 2019

To cite this article: Sozen, E. (2019). High School Students' Views and Attitudes towards Geography Courses in Turkey. Review of International Geographical Education Online (RIGEO), 9(2), 458-478. Retrieved from http://www.rigeo.org/vol9no1/Number1Spring/RIGEO-V9-N2-10.pdf

DOI: $10.33403 /$ rigeo.566402

Submitted: $16.04 .2019 \quad$ Revised: $17.07 .2019 \quad$ Accepted: 13.08 .2019

\title{
High School Students' Views and Attitudes towards Geography Courses in Turkey
}

\author{
Erol SÖZEN ${ }^{1}$ \\ Duzce University, Duzce, TURKEY
}

\begin{abstract}
Geography, which is very important in understanding the place we live on, should be an area of interest for students rather than just a course. Geography education is an important subject in Turkey that has been offered in various institutions from pre-school to post-graduate education. The first geography course curriculum began to be implemented in 1924 in the history of the Republic. Geography course curricula (GCC), as in other courses, have also been changed since 1924. With the amendment of 2005, the GCC has reached a very different structure than the previous curricula and has entered into the application with many changes and innovations. The Geography Curriculum had new revisions and innovations in 2018 as well. Despite these changes, the curriculum's structure has not been changed. Students centered instruction, construvtivist approach, and active learning strategies were the heart of the curriculum. The aim of this study was to determine the views of high school students studying in Düzce province about in-class learning-teaching activities, material use in geography courses and their attitudes towards geography courses based on these, and to examine this subject in terms of various variables (gender of student, gender of the geography teacher, whether the course is liked, school location, class level and school type). Survey model was used in this study. For this purpose, a scale was developed for the study. A 25-item "learning process in geography course, material use and student attitude" scale consisting of three factors including developed. The study group consists of 568 students studying in various high schools in Düzce during the 2018-2019 academic year. Statistical analyzes were performed using SPSS 22.0 (Statistical Package for Social Science for Personal Computers) software. The results indicated that even though the 2018 revised curriculum implemented active learning, constructivist approach, and student centered program, teachers utilize traditional instructional methods according to students. Teachers mainly use textbooks and they hardly use instructional materials. Results also indicated that teachers only use traditional assessment methods. The use of student portfolios, group work, and student projects hardly exist in classrooms.
\end{abstract}

\section{Keywords}

Geography Curricula; Student Viewpoints, Material Use; in-Class Activities

${ }^{1}$ Assist. Prof.; Duzce Universtiy, Faculty of Education, E-mail: erolsozen [at] duzce.edu.tr, ORCID: 0000-0002-0522-4527

(C) Review of International Geographical Education Online

RIGEO 2019

ISSN: 2146-0353

www.rigeo.org 
Geography, which is very important in understanding the place we live on, should be an area of interest rather than just a course for students. Geography education is an important subject in Turkey that has been offered in various institutions from pre-school to post-graduate education. The success of the course curriculum can be achieved with the participation of teachers and students in the implementation of the program. (Ertürk, 1984; Varış, 1998).

The first geography course curriculum began to be implemented in 1924 in the history of the Republic. Geography course curricula (GCC), as in other courses, have also changed from 1924 until today. In 1942, 1957, 1971, 1973, 1982, 1983, 1992, changes were made in the GCCs (Gülersoy, 2007). In the GCC, which started to be implemented in 1942, the traces of the decisions of the First Geography Congress are worthy of notice. As of 1942, the topics of Turkey's geography have been included in the program as seven geographical regions and 21 districts. This is a significant change in terms of content (MEB, 1942). In addition, while the USA and European countries updated their curricula after World War II, there was not any serious attempt in revising GCC in Turkey until 1957. The 1957 program, on the other hand, was prepared by being influenced, albeit little, by the changes that took place after World War II and began to be implemented (Aydın \& Güngördü, 2015; Akkuş, 2008; Sözen E., 2011). Until 2005, geography curricula were developed as teacher centered. But, the revisions introduced in 2005 and later, required students to be in the center of the curricula and instruction. Therefore, students' opinions and attitudes are very important to have a successful implementation of the geography curriculum. From the $1^{\text {st }}$ Education Council on July $17-29,1939$ to the $13^{\text {th }}$ National Education Council on January 15-19, 1990, the search for better continued in the education system, and solutions to problems were sought for the education system (Sakaoğlu, 1992). Considering the fact that such curriculum improvement work continues today, it is difficult to say that a sufficient number of solutions related to the problems of the education system were found. If all these efforts were successful enough, they will be more permanent and well established in the education system and curricula, and simple revisions can be sufficient for the requirements of the era. Unfortunately, there is no permanent solution found in the Turkish education system and it seems that the system is not fully established. In Turkey, there are frequent quests and studies for course curricula. Continuous experimenting with the system is dominant in the system. For example, one of these trials is remembered as the 1991-1992 credit system (Y1lmaz \& Zeyrek, 1997). This model was implemented as a pilot program in schools with suitable infrastructure for the first year and then implemented in all secondary schools starting from the 19921993 school year (Sözer, 1998). Although this system was implemented for a short period of time, the fact that pilot applications and trials were performed was an appropriate approach for the program change. Because the education programs that were implemented in 2005 and afterwards have not gone through a pilot application or the filters of schools (Sözen, 2018). Geography, which has been neglected in today's Turkish education system, displays an image that has been confined in the field of Social Sciences and transformed into an infertile discipline, is far from meeting the needs of scientific committies and society in this form (Artvinli, 2007). It is notable that 
the rapidly developing Geography in Europe and America is less popular in our country than it was in the 1950s, and that for years, non-experts have intervened in the Geography curricula (Alım, 2003).

A considerable consensus among academics and teachers in Turkey that geography education approach and curriculum development studies do not progress very positively, and therefore, there is a need for a revision movement, even a reform, starting from high school geography education (Tomal, 2004). The GCC revisions have not yet brought geography education to the desired level. They could not save geography courses from its unappealing condition. In the United States in 1994, geography has become one of the four core courses. In fact, "Geography" has been recognized as one of the four most important and strategic courses including mathematics, science and technology by the Education Department of NASA. (Bednarz, Mark and Fred, 2005). Geography, which has been accepted as an important course and field in developed countries, has been pushed aside in Turkey and left as an unimportant course. As a matter of fact, in addition to exploring both the commercial and the occupational problems of the world, which tend to increase locally and globally, geography education makes significant contributions to the country' value in political fields as well (Artvinli, 2007). Now geography in the modern world is not regarded as a course where the characters of places and locations and some of the usual properties are memorized in a monotonous manner. While it was thought that geography was a course in which students were expected to memorize names of the places in the past (Şahin, 2001), today, it is believed especially in developed countries that almost all social, natural and economic problems can be solved by individuals who are well-trained in geography (National Academy Press, 1997).

Indeed, despite the increasing importance of geography education in developed countries, the current negative approach in Turkey causes difficulties in adapting the teaching of globalization, climate change, natural events and disasters (earthquakes, floods, overflow of water from water bodies, etc.), environmental education, geography teaching technologies (GTT etc.) and other global problems and phenomena involving local elements to the daily life (Artvinli, 2007). Information that is not used, or cannot be associated with daily life, is not considered very appealing and necessary by the students. Such situations make geography courses boring and unappealing.

The curriculums implemented before 2005 were designed to force students to memorize the knowledge (Artvinli, 2007). Even worse is the fact that the students, who have grown up deprived of real geographical knowledge, skills and perspective for years, are in the chaos of seeking remedies for many problems arising from geographical reasons with methods that are far away from geographical knowledge and perspective as individuals and governors of today's Turkish society. Thus, a significant number of geographers have been deprived from geography's main ideology; learning useful information and using them for the benefits of the society.

In order to solve the problems in geography education programs and the teaching of this course, the importance of restructuring of geography has been emphasized in the context of some action points taking into consideration the special conditions of Turkey 
based upon the Geography Reform in the USA. In this context, the following results are listed: because

- Geography is important for regional and world leadership,

- Teachers and faculty should work together on this,

- Political support is vital for geography (education) reform,

- The leadership of institutions is important,

- It needs to be focused on the concepts rather than topics,

- There are concepts (topics) of geography that have not gained enough importance in Turkey (Ar1, 2003, p. 140).

Although the general objectives of geography teaching are important, Doğanay (1993) collected the primary objectives of geography teaching under the three headings: geography in acquiring a love for the homeland, geography in the homeland defence, and geography in managing the country.

It is crucially important that geography, whose teaching has the above mentioned important results and objectives, become a subject which students enjoy more and value more.

GCC, which started to be implemented in 1924 and realized one of its important stages with the First Geography Congress in 1941, has been revised many times until today. GCC underwent a radical change in 2005. The Ministry of National Education and The Board of Education and Discipline reviewed the GCC again. The GCC amendment studies started in 2002 and were adopted with Article 198 dated 14.07.2005. With the amendment of 2005, the GCC has reached a very different structure than the previous curricula and has entered into the application with many changes and innovations. The GCC, adopting a constructivist approach, brought a structure with multiple intelligence-based goals with learner-centred and active learning, away from memorization. In addition, it is more focused on process-based evaluation than resultbased evaluation in the assessment and evaluation processes. Classroom activities should be carried out according to this structure. It is vital that this structure is well understood by geography teachers. The learning outcome-based structure of the program gives much more importance to learning outcome than textbooks. So, textbooks are just a tool for this GCC, not a goal. This has provided the teachers with a wide range of flexibility for out-of-class activities. However, the 2005 GCC was implemented without a piloting phase as opposed to previos GCCs. Previos GCCs rechecked and applied in pilot application schools or regions. After all these preliminary studies and necessary amendments, the curriculum would start to be implemented in all schools. But, these procedures were not followed in the 2005 GCC.

When the literature is examined, it is seen that various studies have been carried out on GCCs. Akkuş (2008), Aksoy (2004), Aksoy ve Koç (2010), Alım (2003), Arı (2003), Artvinli (2007), Artvinli (2010), Doğanay (1989), Ertürk and Girgin (2005), Geçit (2008), İncekara (2006), Karabağ ve Şahin (2007), Kerski (2000), Oruç, Tokcan and Demirkaya (2017), Sezer and Tokcan (2003), Tanoba (2002), Taş (2002), Tomal (2004) are some of the researchers who have conducted important studies about the student or teacher views on GCC. While these studies focused on general student and teacher 
attitudes, the current study also investigated in-class activities and the level of material usage.

\section{The Aim of the Study}

The 2005 GCC has been presented to all schools without any pilot application or amendment. This situation in particular necessitated recommendations for a good understanding and proper application of the GCC. It is important to evaluate the various aspects of the curriculum and continue the process with the feedback. In light of all of these, the following problem situation was studied in this study.

The aim of this study was to determine the views and attitudes of high school students studying in Düzce province about in-class learning-teaching activities, material use in geography courses. Based on these, examine various variables (gender of student, gender of the geography teachers, whether the course is liked, school location, class level and school type). The following sub-questions were also answered by this study:

1. What are the high school students' attitudes towards geography courses?

2. What are the high school students' opinions on in-class activities?

3. What are the high school students' opinions on material use?

\section{Methodology}

This section focuses on the research model, study group, data collection tools, data collection and data analysis.

\section{Research Design}

Survey model was used in this study. Survey research is a study aiming to collect data in order to determine the specific characteristics of a group (Büyüköztürk et al., 2018). Survey method is a preferred research method in social sciences (Ekiz, 2015; Borg \& Gall, 1971). For this purpose, a scale was developed for the study (Sözen, 2019). The survey model, which is conducted through questionnaires, is based on describing the current situation as it is (Ekiz, 2015; Karasar, 2016). For this research, the survey is an important tool to reach statistical information.

\section{Data Collection and Data processing}

The study used 'learning process in geography course, material use and student attitude' developed by Sözen (2019). It was applied to 371 high school students consisting of 104 male and 267 female students, in Düzce, in 2018. Then, reliability studies were conducted. As a result of this pre-application, the items with insufficient quality, i.e. items with a weighted value less than .30 were excluded from the questionnaire, and a more reliable measurement tool was tried to be provided. The 1st, $2^{\text {nd }}, 4^{\text {th }}, 9^{\text {th }}$ and $24^{\text {th }}$ items were removed from the scale consisting of 33 items initially as a result of the reliability study. The scale has reached a 3 -factor structure with the reliability study. As a result of this application, the reliability of the scale was ensured. The scale explained $52.95 \%$ of the variance. The KMO (Kaiser-Meyer-Olkin) value of the scale was found as .90. In such scales, the results of KMO above .70 are suitable for the application (Arseven, 2001; Büyüköztürk, 2018; Karasar, 2016). The scale's Cronbach Alpha coefficient value was .90. 
Table 1

Likert Scale Survey Items

\begin{tabular}{lll}
\hline Strongly Disagree & 1 & $1.00-1.80$ \\
\hline Disagree & 2 & $1.81-2.60$ \\
\hline Undecided/Neutral & 3 & $2.61-3.40$ \\
\hline Agree & 4 & $3.41-4.20$ \\
\hline Totally Agree & 5 & $4.21-5.00$ \\
\hline
\end{tabular}

\section{Study Group}

The study group consists of 568 students studying in various high schools in Düzce during the 2018-2019 academic year. This study group consisted of 152 male and 416 female students. Students voluntarily participated in the study. The study was limited to 2018-2019 school year and only high school students in Düzce. The students were also given the opportunity to fill out the scale or revise their answer at any time. Since the scale application was based on voluntary participation, the findings can be considered more realistic (Arseven, 2001). Table 2 shows the demographic data of the study group.

Table 2

Demographic Data of the Study Group

\begin{tabular}{|c|c|c|c|c|c|}
\hline & $\mathbf{N}$ & $\%$ & & $\mathbf{N}$ & $\%$ \\
\hline Gender & & & Geography Teacher's Gender & & \\
\hline Male & 152 & 26.7 & Male & 399 & 70.2 \\
\hline Female & 416 & 73.3 & Female & 169 & 29.8 \\
\hline Total & 568 & 100 & Total & 568 & 100.0 \\
\hline Grade & $\mathbf{N}$ & $\%$ & School Type & $\mathbf{N}$ & $\%$ \\
\hline 9th Grade & 209 & 36.8 & Science High School & 121 & 21.3 \\
\hline 10th Grade & 199 & 35.0 & Anatolian High School & 250 & 44 \\
\hline 11th Grade & 77 & 13.6 & Religious Vocational High School & 121 & 21.3 \\
\hline 12th Grade & 83 & 14.6 & Girls' Vocational School & 76 & 13.4 \\
\hline Total & 568 & 100.0 & Total & 568 & 100.0 \\
\hline School Location & $\mathbf{N}$ & $\%$ & & & \\
\hline Province & 407 & 71.7 & & & \\
\hline District & 161 & 28.3 & & & \\
\hline Total & 568 & 100 & & & \\
\hline
\end{tabular}

\section{Data Analysis}

Statistical analyses were performed using SPSS 22.0 (Statistical Package for Social Science for Personal Computers) software. Descriptive statistics were used in the analysis of the problem statement and sub-problems of the study, and t-test was used for unrelated samples. One-way analysis of variance (ANOVA) was used for unrelated samples. Scheffe Post Hoc test was used for comparison between groups.

\section{Findings}

\section{Findings on High School Students' Attitudes towards Geography Course}

Table 3 presents descriptive data on the views of high school students for the attitude dimension of "learning process in geography course, material and student attitude scale. According to this, the most favorable opinion of the students was for the item "I feel 
like I learn something in Geography courses" (Agree), while the least favorable opinion was for the item "I don't like Geography courses" (Disagree).

Table 3

Percentage Frequency Analysis of the Answers Given to Items in Attitude Dimension of the Scale

\begin{tabular}{|c|c|c|c|c|c|c|c|c|c|c|c|}
\hline \multirow{4}{*}{$\begin{array}{l}\text { Questionnaire } \\
\text { Items }\end{array}$} & \multicolumn{10}{|c|}{ Answer Choices } & \multirow[b]{3}{*}{$\bar{X}$} \\
\hline & \multicolumn{2}{|c|}{$\begin{array}{l}\text { Strongly } \\
\text { Disagree }\end{array}$} & \multicolumn{2}{|c|}{ Disagree } & \multicolumn{2}{|c|}{$\begin{array}{c}\text { Undecided } \\
\text { /Neutral }\end{array}$} & \multicolumn{2}{|c|}{ Agree } & \multicolumn{2}{|c|}{$\begin{array}{l}\text { Strongly } \\
\text { Agree }\end{array}$} & \\
\hline & $\mathrm{f}$ & $\%$ & $\mathrm{f}$ & $\%$ & $\mathrm{f}$ & $\%$ & $\mathrm{f}$ & $\%$ & $\mathrm{f}$ & $\%$ & \\
\hline & \multicolumn{8}{|c|}{ Attitude } & & & \\
\hline $\begin{array}{l}\text { 1. I feel like I learn } \\
\text { something in } \\
\text { geography courses. }\end{array}$ & 29 & 5.1 & 29 & 5.1 & 130 & 22.9 & 206 & 36.3 & 174 & 30.6 & 3.82 \\
\hline $\begin{array}{l}\text { 2. We enjoy learning in } \\
\text { Geography courses. }\end{array}$ & 60 & 10.6 & 61 & 10.7 & 142 & 25 & 132 & 23.2 & 173 & 30.5 & 3.52 \\
\hline $\begin{array}{l}\text { 3. We have fun in } \\
\text { geography courses. }\end{array}$ & 76 & 13.4 & 69 & 12.1 & 138 & 24.3 & 140 & 24.7 & 145 & 25.5 & 3.36 \\
\hline $\begin{array}{l}\text { 4. I don't like } \\
\text { geography courses. }\end{array}$ & 169 & 29.8 & 140 & 24.7 & 107 & 18.8 & 84 & 14.8 & 68 & 11.9 & 2.54 \\
\hline $\begin{array}{l}\text { 5. We lose track of } \\
\text { time in Geography } \\
\text { courses. }\end{array}$ & 106 & 18.7 & 117 & 20.6 & 141 & 24.8 & 120 & 21.1 & 84 & 14.8 & 2.92 \\
\hline \multirow{5}{*}{$\begin{array}{l}\text { 6. We do fun activities } \\
\text { in Geography courses. } \\
\text { 7. I get bored in the } \\
\text { Geography courses. } \\
\text { 8. I look forward to the } \\
\text { Geography courses. } \\
\text { 9. I'd rather have } \\
\text { another course instead } \\
\text { of Geography. }\end{array}$} & 136 & 23.9 & 139 & 24.5 & 131 & 23.1 & 104 & 18.3 & 58 & 10.2 & 2.66 \\
\hline & 129 & 22.7 & 125 & 22 & 151 & 26.6 & 90 & 15.8 & 73 & 12.9 & 2.74 \\
\hline & 153 & 26.9 & 134 & 23.6 & 155 & 27.3 & 64 & 11.3 & 62 & 10.9 & 2.55 \\
\hline & 155 & 27.3 & 102 & 18 & 132 & 23.2 & 76 & 13.4 & 103 & 18.1 & 2.77 \\
\hline & & & & & & Mea & Scor & f Dim & Ision & & 2.98 \\
\hline
\end{tabular}

The average of students' opinions about their attitudes towards geography courses was at "undecided/neutral" level. According to the data in this table, the views of high school students on their attitudes towards geography courses were not very favorable. The data in Table 3 can be interpreted as students do not like and enjoy geography courses very much.

\section{Findings of High School Students' Views about In-Class Activities in Geography Course}

Table 4 shows the descriptive data of high school students' views on the activity dimension of the "learning process in geography course, material and student attitude" scale. According to this, the most favorable opinion of the students was for the item "In geography classes, the teacher draws graphics on the blackboard." (Agree), while the least favorable opinion was for the item "We create graphs on millimetric papers in geography courses" (Strongly disagree). 
Table 4

Percentage Frequency Analysis of Answers Given To Items in Geography Course InClass Activities Dimension of the Scale

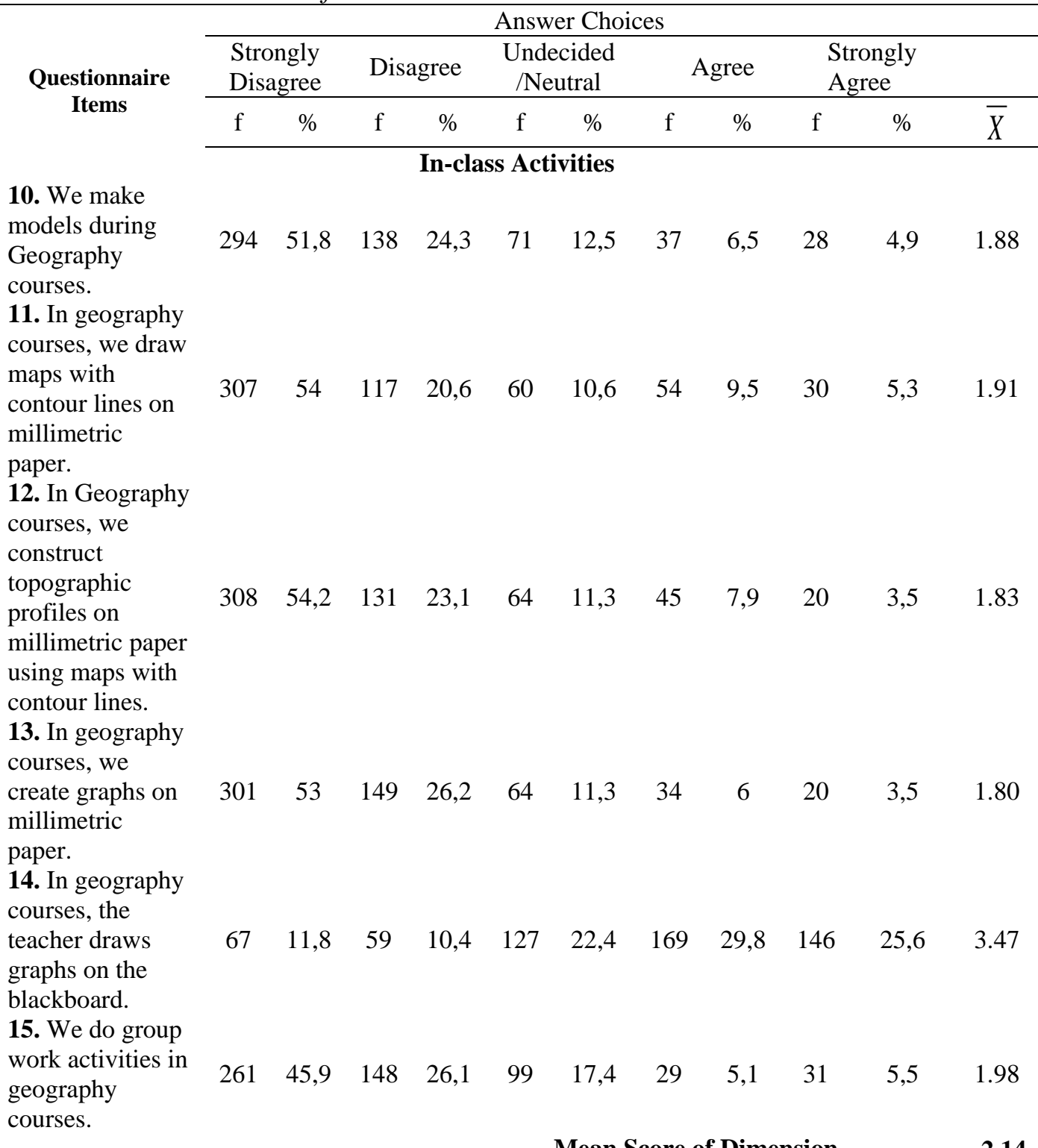

The average of the students' views regarding the items in the dimension of geography in-class activities was at "disagree" level. According to the data in this table, the opinions of high school students regarding the items in the dimension of geography inclass activities were not very favorable. In other words, according to the findings in this table, it can be said that geography courses are not conducted in accordance with the constructivist approach that is an important feature of GCC, students' activities are low, courses are conducted focusing on the use of the board by teachers, not suitable for student-centred and active learning model, and do not address the multiple-intelligence 
approach. In other words, according to Table 4, geography teachers are conducting courses "mostly by giving a lecture and transferring information".

\section{Findings about High School Students' Views on Material Use in Geography Courses}

Table 5 shows the descriptive data of high school students' views on the Material dimension of the "learning process in geography course, material use and student attitude" scale. According to this, the most favorable opinion of the students was for the item "The teacher uses maps while teaching topics in Geography courses" (Agree), while the least favorable opinion was for the item "For my geography course activities, the teacher asks me to prepare an activity file." (Strongly disagree).

Table 5

Percent Frequency Analysis of Answers Given to the Items in the Dimension of Material Use in Geography Courses of the Scale

\section{Questionnaire Items}

16. The teacher uses EBA in the courses while teaching.

17. Our teacher uses a tablet computer while teaching topics in

Geography courses.

18. We use the internet while we learn the topics in

Geography courses.

19. The teacher uses maps while teaching the topics in

Geography courses.

20. We use the Google Earth application in geography courses while we learn topics.

21. We draw graphs with the help of the EXCEL program while learning topics in Geography courses. 22. We watch videos about the topics learned in Geography courses.

23. We use atlas while learning topics in Geography courses.

\begin{tabular}{|c|c|c|c|c|c|c|c|c|c|c|}
\hline \multicolumn{10}{|c|}{ Answer Choices } & \multirow[b]{3}{*}{$\bar{X}$} \\
\hline \multicolumn{2}{|c|}{$\begin{array}{l}\text { Strongly } \\
\text { Disagree }\end{array}$} & \multicolumn{2}{|c|}{ Disagree } & \multicolumn{2}{|c|}{$\begin{array}{c}\text { Undecided } \\
\text { /Neutral }\end{array}$} & \multicolumn{2}{|c|}{ Agree } & \multicolumn{2}{|c|}{$\begin{array}{l}\text { Strongly } \\
\text { Agree }\end{array}$} & \\
\hline $\mathrm{f}$ & $\%$ & f & $\%$ & $\mathrm{f}$ & $\%$ & $\mathrm{f}$ & $\%$ & $\mathrm{f}$ & $\%$ & \\
\hline & & & ateria & Use & & & & & & \\
\hline 217 & 38,2 & 113 & 19,9 & 97 & 17,1 & 91 & 16 & 50 & 8,8 & 2.37 \\
\hline 319 & 56,2 & 100 & 17,6 & 58 & 10,2 & 47 & 8,3 & 44 & 7,7 & 1.93 \\
\hline 107 & 18,8 & 96 & 16,9 & 91 & 16,1 & 147 & 25,9 & 127 & 22,3 & 3.16 \\
\hline 27 & 4,7 & 31 & 5,5 & 100 & 17,6 & 234 & 41,2 & 176 & 31 & 3.88 \\
\hline 246 & 43,3 & 128 & 22,5 & 93 & 16,4 & 59 & 10,4 & 42 & 7,4 & 2.16 \\
\hline 335 & 59 & 146 & 25,7 & 63 & 11,1 & 12 & 2,1 & 12 & 2,1 & 1.62 \\
\hline 161 & 28,3 & 134 & 23,6 & 111 & 19,6 & 87 & 15,3 & 75 & 13,2 & 2.61 \\
\hline 157 & 27,6 & 120 & 21,1 & 130 & 22,9 & 100 & 17,6 & 61 & 10,7 & 2.62 \\
\hline
\end{tabular}


CRIGEO, $9(2)$, Summer 2019

$\begin{array}{lllllll}79 & 13,9 & 30 & 5,3 & 14 & 2,5 & 1.80\end{array}$
file.

The average of the students' views regarding the items in the dimension of material use in Geography courses was at "disagree" level. According to the data in Table 5, it can be said that high school students they do not use enough materials in their geography courses. This situation can be interpreted as geography courses are not conducted based on concrete, tangible forms but rather in an abstract manner. In such a course environment, it is possible to talk about a course environment that is not sufficiently visual and far from the theory of multiple intelligences. Looking at the items 16, 17, 18, 20, and 22 in the scale, it can be said that EBA (Education Technology Network) is not used sufficiently and teachers are not using the Fatih Project infrastructure for Geography courses. This situation can be interpreted as that there is not enough technology use in Geography courses. Failure to create student portfolios can be expressed as a negative situation for both project-based learning and process evaluation (Sözen \& Coşkun, 2017). It can be said that in-service trainings for the use of technology are insufficient (Şanl, Altun, Tan, 2015). In short, this can be interpreted as that the group activities and process evaluation that are important for GCC are not performed at sufficient levels. Based on the descriptive analyzes in Table 3, 4, and 5, it can be said that geography teachers do not conduct geography courses in accordance with GCC and student-centred activities are inadequate. This situation may not save geography courses from being unpleasant and unappealing (Sözen \& Coşkun, 2017; Alim, 2008).

\section{Findings Related to Gender Differences Based on the Students' Opinions in "Learning Process in Geography Course, Material Use and Student Attitude" Scale}

Table 6 shows independent groups t-test results, conducted to show whether students' views differ significantly according to their gender in "learning process in geography course, material use and student attitude" scale. According to Table 6, there is a significant difference between gender and attitude, one of the lower dimensions of the scale, in favor of male students. [ $t(566)=-2,499 ; p<.05]$. 
Sozen, E. (2019) / High School Students' Views and Attitudes towards Geography Courses in Turkey....

Table 6

Independent groups t-test results on whether the sub-dimensions of the "learning process in geography course, material use and student attitude" scale differ according to the gender of the students

\begin{tabular}{|c|c|c|c|c|c|c|c|}
\hline Dimensions & Gender & $\mathbf{n}$ & $\bar{X}$ & $\mathbf{S}$ & Sd & $\mathbf{t}$ & $\mathbf{p}$ \\
\hline \multirow[t]{2}{*}{ Attitude } & Male & 152 & 3.07 & 0.47 & 566 & -2.499 & 0.01 \\
\hline & Female & 416 & 2.96 & 0.48 & & & \\
\hline \multirow[t]{2}{*}{ Activity } & Male & 152 & 2.13 & 0.89 & 566 & -0.204 & 0.83 \\
\hline & Female & 416 & 2.15 & 0.82 & & & \\
\hline \multirow[t]{2}{*}{ Material } & Male & 152 & 2.36 & 0.84 & 566 & -0.653 & 0.51 \\
\hline & Female & 416 & 2.41 & 0.71 & & & \\
\hline \multirow[t]{2}{*}{ Scale General } & Male & 152 & 2.56 & 0.60 & 566 & 0.364 & 0.71 \\
\hline & Female & 416 & 2.54 & 0.50 & & & \\
\hline
\end{tabular}

When the arithmetic averages between the genders are considered $(\overline{\mathrm{X}}$ (male) $=3.07<\overline{\mathrm{X}}$ (female) $=2.96$ ), it is seen that the arithmetic average of male students is higher. There is no significant difference in activity and material dimensions according to the gender of high school students. However, it was seen that the scores of female students were higher than males in the arithmetic mean of activity and material dimension. Student opinions were at the level of $\left(\bar{X}_{(\text {male })}=3.07<\bar{X} \quad\right.$ (female) $\left.=2.96\right)$, 'undecided $/$ neutral' in the attitude dimension of the scale; at the level of $\left(\bar{X}_{\text {(male) }}=2.13<\bar{X}\right.$ (female) $\left.=2.15\right)$, 'disagree' in the activity dimension of the scale; at the level of (male) $=2.36<6$ ( female $=2.41$ ), 'disagree' in the material use dimension of the scale; at the level of $\bar{X}_{(\text {female })=2.54<\bar{X}}$ (male)=2.56), 'disagree' throughout the scale. This situation shows that the students do not like geography courses very much, they do not have a very positive opinion about activities in the course, and they do not express very positive opinions about the use of materials in the course activities.

\section{Findings Related to the Differences of High School Students' Views on the "Learning Process in Geography Course, Material Use and Student Attitude" Scale Based on Their Attitudes towards Geography Courses}

In Table 7, results of independent groups' t-test on whether the "learning process in geography course, material use and student attitude" scale shows a significant difference according to whether students like geography courses can be seen. Based on the table, there is a significant difference between whether students like geography courses and attitude, one of the lower dimensions of the scale $[t(566)=-2.375 ; p<.05]$.

When the arithmetic averages about students' liking geography courses are examined, it is observed that the students who like geography course also have a high arithmetic average score in terms of their attitude $\left(\bar{X}_{(\text {likes })}=2,91<\bar{X}_{(\text {does not like })}=3,02\right)$. 
Table 7

Independent groups' t-test results on whether the sub-dimensions of the "learning process in geography course, material use and student attitude" scale differ according to whether students like geography courses

\begin{tabular}{|c|c|c|c|c|c|c|c|}
\hline Dimensions & Status & $\mathbf{n}$ & $\bar{x}$ & $\mathbf{S}$ & Sd & $\mathbf{t}$ & $\mathbf{p}$ \\
\hline \multirow{2}{*}{ Attitude } & Does not like & 152 & 2.91 & 0.51 & \multirow{2}{*}{566} & \multirow{2}{*}{-2.375} & \multirow{2}{*}{0.01} \\
\hline & Likes & 416 & 3.02 & 0.46 & & & \\
\hline \multirow{2}{*}{ Activity } & Does not like & 152 & 1.98 & 0.79 & \multirow{2}{*}{566} & \multirow{2}{*}{-2.896} & \multirow{2}{*}{0.00} \\
\hline & Likes & 416 & 2.21 & 0.85 & & & \\
\hline \multirow{2}{*}{ Material } & Does not like & 152 & 2.31 & 0.79 & \multirow{2}{*}{566} & \multirow{2}{*}{-1.664} & \multirow{2}{*}{0.09} \\
\hline & Likes & 416 & 2.43 & 0.73 & & & \\
\hline \multirow{2}{*}{ Scale General } & Does not like & 152 & 2.44 & 0.57 & \multirow{2}{*}{566} & \multirow{2}{*}{-2.807} & \multirow{2}{*}{0.00} \\
\hline & Likes & 416 & 2.59 & 0.51 & & & \\
\hline
\end{tabular}

According to Table 7, there is a significant difference between whether students like geography courses and activity, one of the lower dimensions of the scale $[t(566)=-$ $2,896 ; p<.05]$. When the arithmetic averages related to students' liking of geography courses are examined, it is seen that the students who like geography course also have a high arithmetic mean score in terms of their opinions about the in-class activities of this course $\left(\overline{\mathrm{X}}_{\text {(does not like) }}=1.98<\overline{\mathrm{X}}_{\text {(likes) }}=2.21\right)$.

According to Table 7, there is no significant difference found between whether students like geography courses and "material use", one of the lower dimensions of the scale $[t(566)=-1.664 ; p>.05]$. When the arithmetic averages related to students' liking of geography courses are examined, it is seen that the students who like geography course also have a high arithmetic mean score in terms of their opinions about the material use in courses $\left(\bar{X}_{\text {(does not like) }}=1,98<\bar{X}_{(\text {likes })}=2,21\right)$.

According to Table 7, there is a significant difference between the students' liking of geography courses and their views on the scale in general in favor of the students who like geography courses. $[t(566)=-2.807 ; p<.05]$. When the arithmetic average scores about students' liking of geography courses are examined, it is seen that the students who like geography course also have high arithmetic mean scores on their views on the scale in general $\left(\bar{X}_{(\text {does not like })}=2.44<\bar{X}_{(\text {likes })}=2.59\right)$. However, the general average of the scale shows that even the students who like geography courses have "disagree" $(\bar{X}=2.59)$ level in terms of their views on the scale. In other words, both students who like and dislike the course did not find the classroom activities and materials used in geography course adequate in general.

\section{Findings on the Differences of High School Students ' Views Based on Geography Teacher's Gender in "Learning Process in Geography Course, Material Use and Student Attitude" Scale}

Table 8 shows independent groups t-test results on whether the "learning process in geography course, material use and student attitude" scale differ according to the gender of the teacher. According to Table 8, there is a significant difference between gender of the geography teachers and attitude, one of the lower dimensions of the scale, in favor 
of male geography teachers $[t(566)=3.409 ; p<.05]$. When the mean average scores difference between the genders of the geography teachers are examined, it is seen that the mean average score of male geography teachers is higher than that of female geography teachers $\left(\overline{\mathrm{X}}_{(\text {male })}=3.03<\overline{\mathrm{X}}_{\text {(female })}=2.88\right)$. In other words, according to Table 8 , students can be said to have a more positive attitude towards the courses of male geography teachers.

Table 8

Independent groups t-test results on whether the sub-dimensions of the "learning process in geography course, material use and student attitude" scale differ according to the gender of the teacher

\begin{tabular}{|c|c|c|c|c|c|c|c|}
\hline Dimensions & Gender & $\mathbf{n}$ & $\bar{x}$ & $\mathbf{S}$ & Sd & $\mathbf{t}$ & $\mathbf{p}$ \\
\hline \multirow{2}{*}{ Attitude } & Male & 399 & 3.03 & 0.49 & \multirow{2}{*}{566} & \multirow{2}{*}{3.409} & \multirow{2}{*}{0.00} \\
\hline & Female & 169 & 2.88 & 0.44 & & & \\
\hline \multirow{2}{*}{ Activity } & Male & 399 & 2.14 & 0.84 & \multirow{2}{*}{566} & \multirow{2}{*}{-.359} & \multirow{2}{*}{0.72} \\
\hline & Female & 169 & 2.16 & 0.83 & & & \\
\hline \multirow{2}{*}{ Material } & Male & 399 & 2.48 & 0.72 & \multirow{2}{*}{566} & \multirow{2}{*}{4.007} & \multirow{2}{*}{0.00} \\
\hline & Female & 169 & 2.20 & 0.77 & & & \\
\hline \multirow{2}{*}{ Scale General } & Male & 399 & 2.59 & 0.52 & \multirow{2}{*}{566} & \multirow{2}{*}{3.208} & \multirow{2}{*}{0.01} \\
\hline & Female & 169 & 2.44 & 0.55 & & & \\
\hline
\end{tabular}

Student views on in-class activities did not show a significant difference in terms of gender of teachers. $[t(566)=-, 359 ; p>, 05]$. It was observed that the mean scores of male and female geography teachers were close to each other according to student views $\left(\bar{X}_{\text {(male) }}=2.14<\bar{X}_{(\text {female })}=2.16\right)$. Students' views on the use of materials in the courses differed in favor of male teachers according to the gender of the geography teacher. $[\mathrm{t}(566)=4.007 ; \mathrm{p}<.05]$. Looking at the overall scale, it was observed that the views of the students showed a significant difference in favor of male teachers $[t(566)$ $=3.208 ; \mathrm{p}<.05]$.

According to these average scores, students regard geography courses of male geography teachers more positive $\left(\bar{X}_{\text {(female })}=2.44<\bar{X}(\right.$ male $\left.)=2.59\right)$. Although the gender of geography teachers affected students' attitudes towards geography courses, their attitude level was "undecided/neutral". According to the gender of the geography teachers, it has been observed that the student's views appear at the level of "disagree" throughout the scale.

\section{Findings on the Differences of High School Students' Opinions Based on the Location of the School in "Learning Process in Geography Course, Material Use and Student Attitude" Scale}

Table 9 shows the independent groups t-test results on whether the "learning process in geography course, material use and student attitude" scale differ according to the location of school. According to Table 9, there is no significant difference between the location of the school and attitude, one of the lower dimensions of the scale $[t(566)=-$ $0.022 ; p>.05]$. 
Table 9

Independent groups't-test results on whether the sub-dimensions of the "learning process in geography course, material use and student attitude" scale differ according to the location of school

\begin{tabular}{|c|c|c|c|c|c|c|c|}
\hline Dimensions & Location & $\mathbf{n}$ & $\bar{X}$ & $\mathbf{S}$ & Sd & $\mathbf{t}$ & $\mathbf{p}$ \\
\hline \multirow{2}{*}{ Attitude } & Province & 407 & 2.99 & 0.48 & \multirow{2}{*}{566} & \multirow{2}{*}{-0.022} & \multirow{2}{*}{0.98} \\
\hline & District & 161 & 2.99 & 0.47 & & & \\
\hline \multirow{2}{*}{ Activity } & Province & 407 & 2.25 & 0.86 & \multirow{2}{*}{566} & \multirow{2}{*}{4.692} & \multirow{2}{*}{0.00} \\
\hline & District & 161 & 1.88 & 0.72 & & & \\
\hline \multirow{2}{*}{ Material } & Province & 407 & 2,46 & 0.79 & \multirow{2}{*}{566} & \multirow{2}{*}{3.372} & \multirow{2}{*}{0.00} \\
\hline & District & 161 & 2.23 & 0.61 & & & \\
\hline \multirow{2}{*}{ Scale General } & Province & 407 & 2.60 & 0.55 & \multirow{2}{*}{566} & \multirow{2}{*}{3.652} & \multirow{2}{*}{0.00} \\
\hline & District & 161 & 2.42 & 0.46 & & & \\
\hline
\end{tabular}

When the arithmetic mean scores of the attitude dimension according to the location is considered, it is seen that the mean scores are equal to each other $\left(\bar{X}_{\text {(province })}=2.99<\bar{X}\right.$ $($ district $)=2.99)$. According to Table 9, there was a significant difference between the location of the school and activity, one of the lower dimensions of the scale, in favor of the students studying in the provincial center schools [t $(566)=4.692 ; \mathrm{p}<.05$ ] According to the table, there was a significant difference between the location of the school and material dimension of the scale in favor of the students studying in the provincial center schools $[\mathrm{t}(566)=3.372 ; \mathrm{p}<.05]$. According to the table, there was a significant difference between the location of the school and the scale in general in favor of the students studying in the provincial center schools [ $\mathrm{t}(566)=3.652 ; \mathrm{p}<.05]$. The mean scores of the students according to the location of the school was found at the level of "undecided/neutral" in attitude dimension ( $\bar{X}$ (district) $=2.99<\bar{X}$ (province) $=2.99$ ), at the level of "disagree" in the activity dimension $\left(\bar{X}_{\text {(district) })=1.88<\bar{X}}\right.$ (province)=2.25), at the level of "disagree" in material use dimension $(\bar{X}$ (district) $=2.23<\bar{X}$ (province) $=2.46$ ) and at the level of "disagree" throughout the scale $(\bar{X}$ (district) $=2.42<\bar{X}$ (province)=2.60). This situation showed that there is a relationship between the location of schools and the physical conditions of the schools, and provincial center schools generally have more advantageous physical facilities.

\section{Findings Related to the Differences of High School Students' Views in the "Learning Process in Geography Course, Material Use and Student Attitude" Scale Based on their Grade level}

Table 10 shows the results of the one-way analysis of variance (ANOVA) showing whether there is a significant difference between the grade levels of the students and the "learning process in geography course, material use and student attitude" scale. According to Table 10, there is a significant difference between the grade of students and attitude sub-dimension of the "learning process in geography course, material use and student attitude" scale $[F(3-564)=17.508 ; p<.05]$. 
Sozen, E. (2019) / High School Students' Views and Attitudes towards Geography Courses in Turkey....

Table 10

ANOVA results regarding whether the sub-dimensions of the "learning process in geography course, material use and student attitude" scale differ according to the grade/class level

\begin{tabular}{|c|c|c|c|c|c|c|c|c|c|c|}
\hline 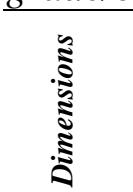 & $\begin{array}{l}\text { Grade } \\
\text { Level }\end{array}$ & $n$ & $\bar{X}$ & SS & $\begin{array}{l}\text { Sum of } \\
\text { Squares }\end{array}$ & df & $\begin{array}{c}\text { Squares } \\
\text { Avg. }\end{array}$ & $\mathrm{F}$ & $p$ & $\begin{array}{c}\text { Differe } \\
\text { nce } \\
\text { Tukey }\end{array}$ \\
\hline \multirow{5}{*}{ 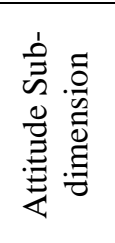 } & $9^{\text {th }}$ Grade & 209 & 2.91 & 0.49 & \multirow{5}{*}{11.315} & & \multirow{5}{*}{3.772} & \multirow{5}{*}{17.5} & \multirow{5}{*}{0.00} & \multirow{5}{*}{$\begin{array}{l}1-3 \\
1-4 \\
2-3 \\
2-4\end{array}$} \\
\hline & $10^{\text {th }}$ Grade & 199 & 2.89 & 0.44 & & 3 & & & & \\
\hline & $11^{\text {th }}$ Grade & 77 & 3.13 & 0.45 & & 564 & & & & \\
\hline & $12^{\text {th }}$ Grade & 83 & 3.27 & 0.43 & & 567 & & & & \\
\hline & Total & 568 & 2.99 & 0.48 & & & & & & \\
\hline \multirow{5}{*}{ 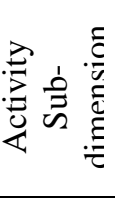 } & $9^{\text {th }}$ Grade & 209 & 2.12 & 0.80 & \multirow{5}{*}{33.208} & 3 & \multirow{5}{*}{11.069} & & & \\
\hline & $10^{\text {th }}$ Grade & 199 & 1.94 & 0.72 & & 3 & & \multirow{4}{*}{16.7} & \multirow{4}{*}{0.00} & $1-3$ \\
\hline & $11^{\text {th }}$ Grade & 77 & 2.72 & 1.02 & & 564 & & & & $2-3$ \\
\hline & $12^{\text {th }}$ Grade & 83 & 2.15 & 0.80 & & & & & & $3-4$ \\
\hline & Total & 568 & 2.14 & 0.84 & & 567 & & & & \\
\hline \multirow{5}{*}{ 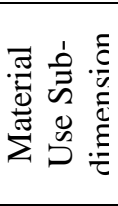 } & $9^{\text {th }}$ Grade & 209 & 2.34 & 0.75 & \multirow{5}{*}{33.337} & & & & & \\
\hline & $10^{\text {th }}$ Grade & 199 & 2.27 & 0.69 & & 3 & \multirow{4}{*}{11.112} & \multirow{4}{*}{21.8} & \multirow{4}{*}{0.00} & $1-4$ \\
\hline & $11^{\text {th }}$ Grade & 77 & 2.26 & 0.64 & & 564 & & & & $2-4$ \\
\hline & $12^{\text {th }}$ Grade & 83 & 2.98 & 0.69 & & 567 & & & & $3-4$ \\
\hline & Total & 568 & 2.40 & 0.75 & & & & & & \\
\hline \multirow{4}{*}{ 苂 } & $9^{\text {th }}$ Grade & 209 & 2.49 & 0.54 & \multirow{4}{*}{15.016} & 3 & \multirow{4}{*}{5.005} & \multirow{4}{*}{19.0} & \multirow{4}{*}{0.00} & $1-3$ \\
\hline & $10^{\text {in }}$ Grade & 199 & 2.41 & 0.49 & & & & & & $1-4$ \\
\hline & $11^{\text {th }}$ Grade & $\begin{array}{l}71 \\
83\end{array}$ & $\begin{array}{l}2.68 \\
288\end{array}$ & 0.47 & & 564 & & & & $2-3$ \\
\hline & Total & 568 & 2.55 & 0.53 & & 567 & & & & $2-4$ \\
\hline
\end{tabular}

According to Tukey, one of the post-hoc tests for the origin of the difference, there are differences between the $9^{\text {th }}$ and $11^{\text {th }}$ graders in favor of the $11^{\text {th }}$ graders, between the $9^{\text {th }}$ and $12^{\text {th }}$ graders in favor of the $12^{\text {th }}$ graders, between the $10^{\text {th }}$ and $11^{\text {th }}$ graders in favor of the $11^{\text {th }}$ graders, and between the $10^{\text {th }}$ and $12^{\text {th }}$ graders in favor of $12^{\text {th }}$ graders. Mean scores of attitude dimension, were found at $\left(\overline{\mathrm{X}}\left(9^{\text {th }}\right.\right.$ grade $\left.)=2,91\right),\left(\overline{\mathrm{X}}_{\left(10^{\text {th }}\right.}\right.$ grade $)=$ $2,89), \quad \bar{X}_{\left(11^{\text {th }}\right.}$ grade $\left.)=3,13\right), \quad\left(\bar{X}_{\left(12^{\text {th }}\right.}\right.$ grade $\left.)=3,27\right)$ level. In particular, a positive increase in students' attitudes towards geography courses can be mentioned starting from $10^{\text {th }}$ grade to $11^{\text {th }}$ and $12^{\text {th }}$ grade. The mean score of the attitude sub-dimension was realized at the level of "undecided/neutral" level $\left(\bar{X}_{\text {(attitude overall) }}=2.99\right)$.

According to Table 10, there is a significant difference between the grade level and the activity sub-dimension of the "learning process in geography course, material use and student attitude" scale. $[F(3-564)=16.788 ; p<.05]$. According to Tukey, one of the Post-hoc tests performed regarding the source of the difference, there are differences between $9^{\text {th }}$ and $11^{\text {th }}$ graders in favor of $11^{\text {th }}$ graders, between $10^{\text {th }}$ and $11^{\text {th }}$ graders in favor of $11^{\text {th }}$ graders, and between $11^{\text {th }}$ and $12^{\text {th }}$ graders in favor of $11^{\text {th }}$ graders. The mean scores of the activity dimension was found as $\bar{X}_{\left(9^{\text {th }}\right.}$ grade $\left.)=2,12\right), \quad \bar{X}\left(10^{\text {th }}\right.$ grade $)=1,94),\left(\bar{X}\left(11^{\text {th }}\right.\right.$ grade $\left.)=2,72\right),\left(\bar{X}\left(12^{\text {th }}\right.\right.$ grade $\left.)=2.15\right)$. Especially in the $11^{\text {th }}$ grade, the 
activity dimension mean score was higher than the other classes. The mean score of the activity sub- dimension was found at "disagree" level $(\overline{\mathrm{X}}($ activity overall $)=2.14)$

According to Table 10, there is a significant difference between the grade level and material use sub-dimension of the "learning process in geography course, material use and student attitude" scale $[F(3-564)=21.803 ; p<.05]$. According to Tukey, one of the Post-hoc tests performed regarding the source of the difference, there are differences between $9^{\text {th }}$ and $12^{\text {th }}$ graders in favor of $12^{\text {th }}$ graders, between $10^{\text {th }}$ and $12^{\text {th }}$ graders in favor of $12^{\text {th }}$ graders and between $11^{\text {th }}$ and $12^{\text {th }}$ graders in favor of $12^{\text {th }}$ graders. The mean scores of the material use dimension was found as $\left(\bar{X}_{\left(9^{\text {th }}\right.}\right.$ grade $\left.)=2,34\right),\left(\bar{X}_{\left(10^{\text {th }}\right.}\right.$ grade $)=2,27), \bar{X}_{\left(11^{\text {th }}\right.}$ grade $\left.)=2,26\right), \bar{X}_{\left(12^{\text {th }}\right.}$ grade $\left.)=2,98\right)$. The mean score of material use sub-dimension was found at "disagree" level $(\overline{\mathrm{X}}($ material use overall $)=2.40)$.

According to Table 10, there is a significant difference between grade levels and all sub-dimensions (attitude, effectiveness, material use) of the "learning process in geography course, material use and student attitude" scale $[F(3-564)=19.094 ; p<.05]$. According to Tukey, one of the Post-hoc tests performed regarding the source of the difference, there are differences between $9^{\text {th }}$ and $11^{\text {th }}$ graders in favor of $11^{\text {th }}$ graders, between $9^{\text {th }}$ and $12^{\text {th }}$ graders in favor of $12^{\text {th }}$ graders, between $10^{\text {th }}$ and $11^{\text {th }}$ graders in favor of $11^{\text {th }}$ graders and between $10^{\text {th }}$ and $12^{\text {th }}$ graders in favor of $12^{\text {th }}$ graders. The mean scores of the whole scale was found as $\left(\bar{X}_{\left(9^{\text {th }}\right.}\right.$ grade $\left.)=2.49\right), \bar{X}_{\left(10^{\text {th }}\right.}$ grade $\left.)=2.41\right), \bar{X}$ $\left(11^{\text {th }}\right.$ grade $\left.)=2.68\right),\left(\bar{X}_{\left(12^{\text {th }}\right.}\right.$ grade $\left.)=2.88\right)$. The mean score of grade level sub-dimension was found at "disagree" level $\left(\overline{\mathrm{X}}_{(\text {General })}=2.55\right)$.

\section{Findings on the Differences of High School Students' Views in the "Learning Process in Geography Course, Material Use and Student Attitude" Scale Based on School Types}

Table 11 presents the results of one-way analysis of variance (ANOVA) showing whether there is a significant difference between the school types of the students participating in the research and "learning process in geography course, material use and student attitude" scale.

Table 11

ANOVA results on whether the sub-dimensions of the "learning process in geography course, material use and student attitude" scale differ according to school types

\begin{tabular}{|c|c|c|c|c|c|c|c|c|c|c|}
\hline 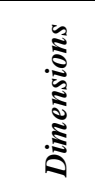 & School Type & $n$ & $\bar{X}$ & SS & $\begin{array}{l}\text { Sum of } \\
\text { Squares }\end{array}$ & df & $\begin{array}{c}\text { Squar } \\
\text { es } \\
\text { Avg. }\end{array}$ & $\mathrm{F}$ & $p$ & $\begin{array}{c}\text { Difference } \\
\text { Tukey }\end{array}$ \\
\hline \multirow{7}{*}{ 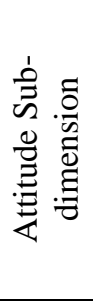 } & Science High & 121 & 3.08 & 0.38 & \multirow{7}{*}{1.753} & \multirow{7}{*}{$\begin{array}{l}564 \\
567\end{array}$} & \multirow{7}{*}{0.584} & \multirow{7}{*}{2.5} & \multirow{7}{*}{0.058} & \\
\hline & School & & & & & & & & & \\
\hline & Anatolian $\mathrm{H}$. & 250 & 2.95 & 0.47 & & & & & & \\
\hline & İHL & 121 & 3.01 & 0.53 & & & & & & \\
\hline & Girls' & 76 & 2.91 & 0.53 & & & & & & \\
\hline & Vocational H. & & & & & & & & & \\
\hline & Total & 568 & 2.99 & 0.48 & & & & & & \\
\hline$=0$ & Science High & 121 & 2.19 & 0.76 & & & & & & \\
\hline
\end{tabular}


Sozen, E. (2019) / High School Students' Views and Attitudes towards Geography Courses in Turkey....

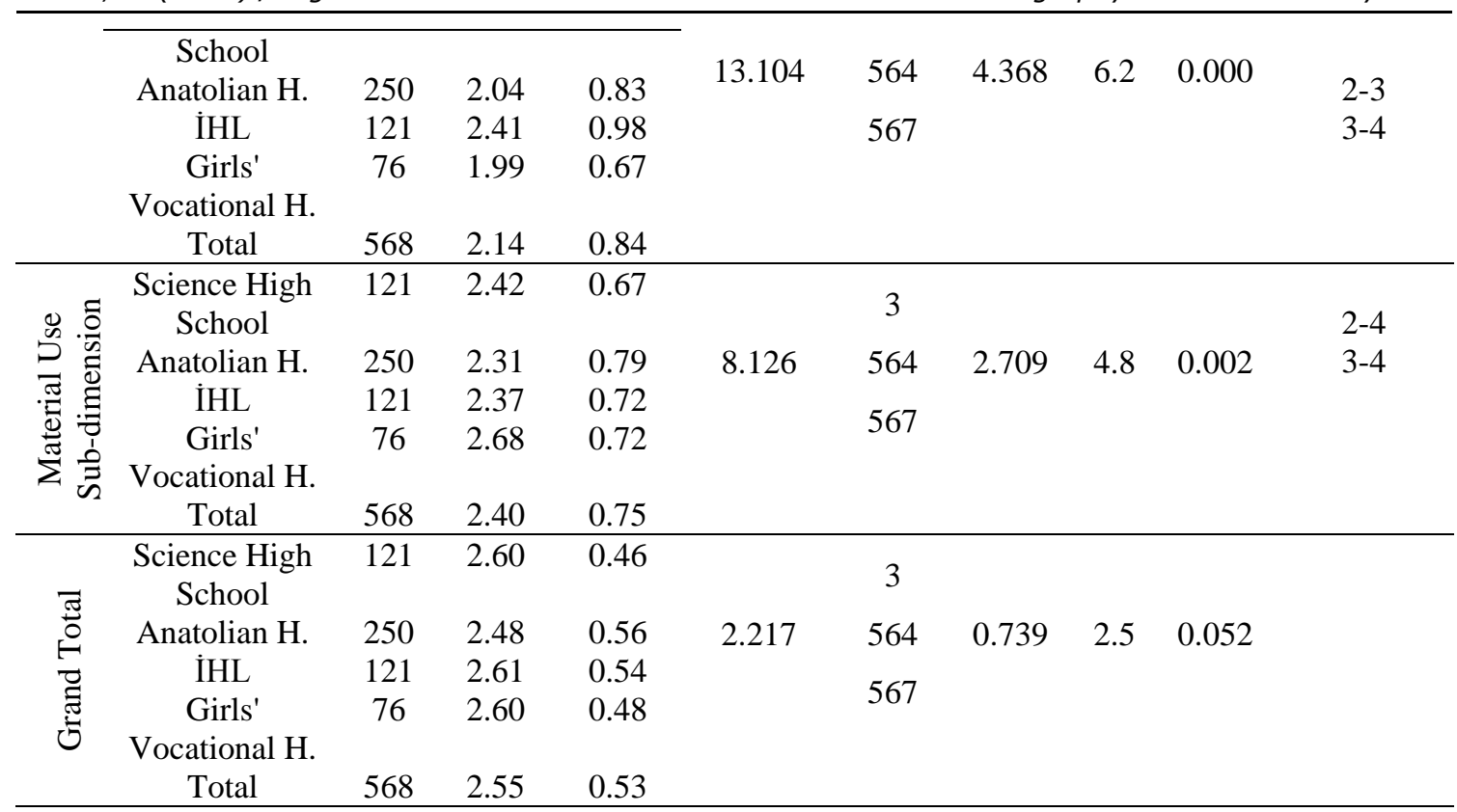

According to Table 11, there is no significant difference between school types and attitude, one of the sub-dimensions of the "learning process in geography course, material use and student attitude" scale $[t(3-564)=2.515 ; p>.05]$. The mean scores

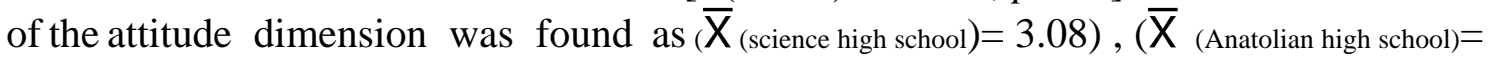

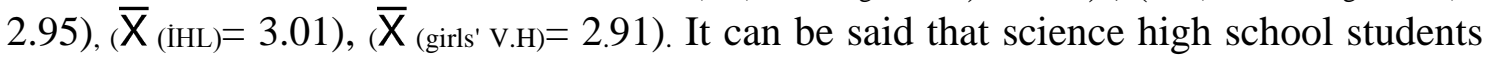
in particular have more positive attitudes towards geography courses. The mean score of the attitude sub-dimension was found at "disagree" level $(\bar{X}$ (school type general $)=2.99)$. According to Table 11, there is a significant difference between the types of school where students study and activity, one of the sub-dimensions of the "learning process in geography course, material use and student attitude" scale $[F(3-564)=6.284 ; p<.05]$. According to Tukey, one of the Post-hoc tests related to the source of the difference, there are differences between Anatolian High Schools and İHL in favor of İHL, and between İHL and Girls' Vocational High Schools in favor of İHL. The mean scores of the activity dimension was found as $(\overline{\mathrm{X}}$ (science high school $)=2.19),(\overline{\mathrm{X}}$ (Anatolian high school $)=$ $\left.\left.2.04), \bar{X}_{(\mathrm{IHL})}=2.41\right), \overline{\mathrm{X}}_{(\text {girls' } \mathrm{V} . \mathrm{H})}=1.99\right)$. The overall mean scores of the activity subdimension was found as $\left(\bar{X}_{\text {(school type general })}=2.14\right)$.

According to Table 11, there is a significant difference between the types of school where students study and material use, one of the sub-dimensions of the "learning process in geography course, material use and student attitude" $[F(3-564)=4.886 ; p<$ .05]. According to Tukey, one of the Post-hoc tests related to the source of the difference, there are differences between Anatolian High School and Girls' Vocational High School in favor of Girls' Vocational High School, and between IHHL and Girls' Vocational High School in favor of Girls' Vocational High School. The mean scores of the material use dimension was found as $(\bar{X}$ (science high school) $=2.42), \quad(\bar{X}$ (Anatolian high

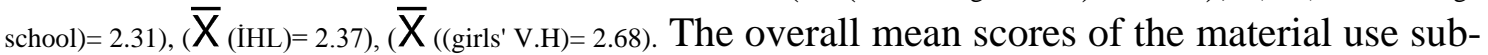
dimension was found as $\left.\bar{X}_{\text {(school type general })}=2.40\right)$. 
According to Table 11, there is no significant difference between school types and all sub-dimensions (attitude, activity, material use) of the "learning process in geography course, material use and student attitude" scale $[t(3-564)=2.595 ; p>.05]$. The mean

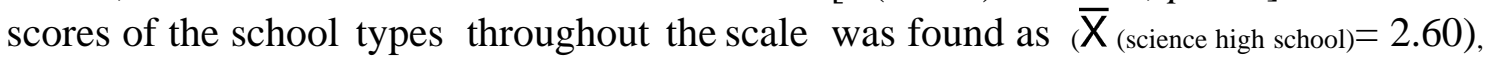
$\left.\left.\overline{\mathrm{X}}_{(\text {Anatolian high school })}=2.48\right),\left(\overline{\mathrm{X}}_{(\mathrm{iHL})}=2.61\right), \overline{\mathrm{X}}_{(\text {girls' } \mathrm{V} . \mathrm{H})}=2.60\right)$. The overall mean score of the grade level was found at "disagree" level $(\bar{X}($ general $)=2.55)$.

\section{Conclusion and Discussion}

The study included 152 male and 416 female students studying at various high schools in Düzce province. The "learning process in geography course, material use and student attitude" scale consisting of 3 factors and 25 items was applied to these students. As a result of this application; the average of the students' attitudes towards geography courses was at the level of "undecided/neutral". These results are in line with the results of Alım (2008). According to this study, high school students' attitudes towards geography courses/courses were not very favorable.

The mean score of the students' opinions on the items in the geography in-class activities and material use dimension was at "disagree" level. According to these findings, it can be said that geography courses are not conducted in accordance with the constructivist approach that is an important feature of GCC, students' activities are low, courses are conducted mostly using the board by teachers, not suitable for studentcentred and active learning model, and do not address the multi-intelligence approach (Artvinli, 2010). Geography teachers can be said to be conducting courses "mostly by giving lecture and transferring information". It can be stated that the proper implementation of GCC has not reached the desired level (Artvinli, 2007). According to this study, high school students stated that they did not use enough materials in geography courses. In this case, it can be said that the contents of the course are not very concretized. It can be said that the infrastructure of Fatih Project is weak for geography courses. These results are in line with the results of the study conducted by Sözen and Coşkun (2017). This suggests that there is not enough technology use in geography courses (Artvinli, 2007; Şanlı et al, 2015). Failure to create a student activity file can be expressed as a negative situation for both project-based learning and process evaluation. In short, according to this study, the group activities and process evaluation that are important for GCC are not sufficient.

Although there is a significant between male and female teachers in favor of male teachers in attitude and material use dimension of the "learning process in geography course, material use and student attitude" scale, according to the gender of the teachers, in the overall scale, students' opinions were at "disagree" level. In the study, the level of map usage was high in terms of material use. This situation is supported by the findings of Öztürk and Eroğlu (2013).

Although, there is a significant difference in favor of the students in the $11^{\text {th }}$ and $12^{\text {th }}$ grades according to the grade level of the "learning process in geography course, material use and student attitude" scale, according to grade levels, in general, the 
student opinions were at "disagree" level. There was also a significant difference for geography courses in the grade level, in the study of Aydin et al. (2010).

Although there are significant differences in favor of IHL and Girls' Vocational High Schools according to the types of schools in the "learning process in geography course, material use and student attitude" scale, according to the types of schools, the students' opinions were at "disagree" level. In the study conducted by Alım (2008), there was no significant difference in school types, but the averages in Anatolian high schools were higher.

Although there is a significant difference in favor of students studying in provincial center schools in the "learning process in geography course, material use and student attitude" scale, in general, students' opinions were at "disagree" level throughout the scale. The material infrastructure of the schools in the city center was also higher in the study of Sözen and Coşkun (2017).

For better implementation of the GCC, which started to be implemented in 2005, it should be discussed and investigated efficiency of in-service training seminars and programs in the past via getting teachers' feedback about those trainings. Geography courses/courses need to be given the necessary importance it deserves in our country, as it is given in Western countries. Geography courses/courses should not be textbookcentered and be conducted in accordance with the learning outcomes. The weight and importance of Geography in the university entrance exams should be increased to equal number of questions with other disciplines. In addition, it should be ensured that teachers implement GCC, and according to feedback of geography teachers, it is needed to create a structure to develop GCC and revised by the Ministry of National Education.

\section{References}

Akkuş, M. (2008). Assessment of geography class teaching program (2005) based on teachers? views. (Unpublished postgraduate thesis). Gazi Uni. Institute of Educational Sciences, Ankara.

Aksoy, B. (2004). Problem based learning approach in geography teaching. (Unpublished doctorate thesis). Gazi Uni. Institute of Educational Sciences, Ankara.

Aksoy, B., \& Koç, H. (2010). The Evaluation Of The Views Of Teachers Concerning The Teaching Program Of 2005 Geography Course. Giresun Uni. Institute of Social Sciences The Black Sea Journal of Social Sciences, 2, 17-52.

Alım, M. (2003). Evaluation of ninth class geography teaching curriculum according to the opinions of teachers and students. (Unpublished doctorate thesis). Atatürk Uni. Erzurum.

Alım, M. (2008). The Attitude of High School Students Towards Geography Course. Eastern Geographical Review, 13(19), 25-32.

Arı, Y. (2003). Amerika Birleşik Devletlerinde Coğrafya Eğitimi Reformu: Türkiye İçin Dersler, Ankara: Türk Coğrafya Kurumu, Coğrafya Kurultayı Bildirileri.

Arseven A, D. (2001). Alan araştırma yöntemi (ilkeler teknikler örnekler). Ankara: Gündüz.

Artvinli, E. (2007). 9. grade geography curriculum in 2005: practicabllty level in point of the teachers. (Unpublished doctorate thesis). Atatürk Uni. Erzurum

Artvinli, E. (2010). Teaching styles of geography teachers. Electronik Journal of Social 
Sciences, 9(33), 387-408.

Aydın F., Coşkun M., \& Kara H. (2010) The attıtudes of commercıal vocatıonal hıgh school students towards geography lesson (elbistan example) Çankırı Karatekin Uni. Journal of Institute of Social Sciences , 1, 183-203.

Aydın, F., \& Güngördü, E. (2015). Coğrafya ĕgitiminde özel öğretim yöntemleri. Ankara, PegemA

Bednarz, S., Mark H. B., \& Fred H. W. (2005). Mentoring: a new approach to geography teacher preparation. Journal of Geography, National Council for Geographic Education, 104, 105-112.

Borg, W.R., \& Gall, M. D. (1971). Educational, research. New York: David McKay Company.

Büyüköztürk Ş., Çakmak E. K., Akgün E. A., Karadeniz Ş., \& Demirel F., (2018) Bilimsel araştırma yöntemleri. Ankara, PegemA.

Büyüköztürk, Ş. (2018) Sosyal bilimler için veri analizi el kitabı. Pegem Akademi. Ankara.

Doğanay, H. (1989). Geography and geography curriculum in our high schools, Ankara: Coğrafya Araştırmaları, Atatürk Kültür Dil ve Tarih Kurumu, Coğrafya Bilim ve Uygulama Kolu, 9(1), 7-24.

Doğanay, H. (1993). Coğrafya'da metodoloji. Ankara: M.E.B.

Ekiz, D. (2015). Bilimsel araştırma yöntemleri. Ankara: Anı.

Ertürk, M., \& Girgin, M. (2005), Comporation geography curriculum in terms of standards. Eastern Geographical Review, Sayl:13, 219-233

Ertürk, S. (1984). Egitimde program geliştirme. Ankara: Hacettepe Üniversitesi.

Geçit, Y. (2008), A work deals with on the programmes of republic term lycee geography education. Journal of Marmara Geography, 18, 149-173.

Gülersoy, A. E. (2007). An evaluation of the new and former $9^{\text {th }}$ and $10^{\text {th }}$ grade geography curriculum. Dokuz Eylül Uni.The Journal of Buca Faculty of Education, 21, 163-173.

İncekara, S. (2006), A comparative evaluation of secondary geographic education in Turkey and Canada: Curriculum, methods and technologies (Unpublished doctorate thesis). Marmara Uni. İstanbul.

Karabağ, S., \& Şahin, S. (Ed.) (2007). Kuram ve uygulamada coğrafya eğitimi. Ankara: Gazi.

Karasar, N. (2016). Bilimsel irade algl çerçevesi ile bilimsel araştırma yöntemi kavramlar ilkeler teknikler. Ankara: Nobel.

Kerski, J.J. (2000). The implementation and effectiveness of Geographic Information Systems Technology and Methods in Secondary Education, Colorado: University of Colorado, Department of Geography.

MEB. (1942). MEB Tebliğler Dergisi, 4, 168.

National Academy Press; Rediscovering Geography; National Academy Pres, Washington, 1997, USA.

Oruç, Ş, Tokcan, H., \& Demirkaya, H. (2017). Yapılandırmacı yaklaşıma bir örnek: Osmanli dönemi coğrafya ve coğrafya öğretimi 2. Baskı (Kişiler, Eserler, Kitaplar, Makaleler, Ders Örnekleri). Ankara: PegemA.

Öztürk, M., \& Eroğlu, E. (2013). Geography Teacher competencies and an evaluation of 
practices. Journal of Marmara Geography, 27, 630-659.

Şahin, C. (2001). Türkiye’de coğrafya öğretimi, sorunlar-çözüm önerileri. Ankara: Gündüz.

Sakaoğlu, N. (1992). Cumhuriyet dönemi eğitim tarihi. İstanbul: İletişim.

Şanl1, Ö. Altun, M. Tan, Ç. (2015) Problems and solution offers of the teachers about smart boards and the tablets delivered to the students. Turkish Studies. 10 (3), 833-850

Sezer, A., \& Tokcan, H. (2003). The effect of cooperative learning on academic achievement in geography course. Gazi Üniversitesi Gazi Uni. Journal of Gazi Edu. Faculty, 23(3), 227242.

Sözen, E. (2011). Assessment of geography 10th grade geography curriculum teaching program based on teachers views. (Unpublished postgraduate thesis). Gazi Uni. Institute of Educational Sciences, Ankara.

Sözen, E. (2018). Teachers' views about the terms acquisition, teaching-learning, and assessment-evaluation processesbased on the $10^{\text {th }}$ grade geography curriculum (2005). Turkish Studies. 13(27), 1305-1322.

Sözen, E. (2019). Development of the scale of towards geography lesson attitude and in-class learning process and material use validity and reliability study. Anatolian Journal of Educational Leadership and Instruction, 7(1), 1-14.

Sözen, E., \& Coşkun, M. (2017). Evaluation of some school applications in Turkish national education according to students' viewpoints. Journal of Education and Training Studies. 5(3), 201-210.

Sözer, E. (1998). Kurumdan uygulama sosyal bilgilerin öğretimi. Eskişehir: Anadolu Üniversitesi.

Tanoba, S. (2002). Evaluation of the geography curriculum for 9 th grade in secondary education. (Unpublished postgraduate thesis). Gazi Uni. Institute of Educational Sciences, Ankara.

Taş, H. İ. (2002). A comparative study of geographic education between the united states and turk1sh high schools. Journal of Marmara Geography, 6, 53-72

Tomal, N. (2004). Problems and solution suggestions of geography curriculum applied in high schools. Journal of Burdur Edu. Faculty, 5(8), 174-188.

Varış, F. (1998). Egitimde program geliştirme. Ankara: Alkım Kitapçılık.

Yllmaz, C., \& Zeyrek, H. (1997). For passing and credit system the place of geography teaching in our high schools according to the system and some problems. OMU Journal of Edu. Faculty, 10(1), 287-307.

\section{Biographical Statement}

Dr. Erol SÖZEN is an assistant professor at the faculty of education in Düzce University. His research focuses are about geography curriculum, methodologies in geographical education and earthquake awareness. 